Original Research Article

\title{
Evaluation of learning and memory effect of atorvastatin and simvastatin in alprazolam induced amnesia in mice
}

\author{
Shashikala G., Jyothi C. H.*, Shashikala G. H.
}

Department of Pharmacology, JJM Medical College,

Davangere, Karnataka, India

Received: 31 July 2018

Accepted: 30 August 2018

*Correspondence to:

Dr. Jyothi C. H.,

Email: dr.jyothich@gmail.com

Copyright: (C) the author(s), publisher and licensee Medip Academy. This is an openaccess article distributed under the terms of the Creative Commons Attribution NonCommercial License, which permits unrestricted noncommercial use, distribution, and reproduction in any medium, provided the original work is properly cited.

\begin{abstract}
Background: The study was undertaken to evaluate the learning and memory effect of lipid lowering drugs atorvastatin and simvastatin in alprazolam induced amnesic mice.

Methods: The study was carried out on albino mice, divided into 4 groups of 6 animals each (either sex, 3-4 months of age, weight 25-30g). Amnesia was induced by administering Alprazolam ( $2 \mathrm{mg} / \mathrm{kg}$ for 14 days) in all 4 groups from $1^{\text {st }}$ to $14^{\text {th }}$ day. In addition, group 2, 3 and 4 received Piracetam $(400 \mathrm{mg} / \mathrm{kg})$, Atorvastatin $(5 \mathrm{mg} / \mathrm{kg})$ and Simvastatin $(5 \mathrm{mg} / \mathrm{kg})$ from $8^{\text {th }}$ to $14^{\text {th }}$ day respectively. The learning and memory of the animals was assessed by employing Elevated plus maze (EPM) and Step-down type passive avoidance (SDA) model.

Results: Results were compared among the different groups using one wayANOVA followed by post hoc Tukey's test. The measured parameters were compared with standard drug Piracetam. In EPM model Atorvastatin $(\mathrm{p}<0.049)$ and Simvastatin $(\mathrm{p}<0.007)$ were comparable with standard drug Piracetam, whereas in SDA model only simvastatin group $(\mathrm{p}<0.001)$ showed significant result.

Conclusions: In EPM model, both the statins showed significant improvement in learning and memory in alprazolam induced amnesic mice. However further studies are required to support these observations.
\end{abstract}

Keywords: Atorvastatin, Alprazolam, Alzheimer's disease, Piracetam, Simvastatin

\section{INTRODUCTION}

Alzheimer's disease (AD) is a neurodegenerative disorder associated with cognitive deficit, begins with memory impairment and spreading to language and visuospatial deficits. It is most often presenting with an insidious onset of memory loss followed by a slowly progressive dementia over several years. Factors like age, head injury, smoking, lower social engagement and Apolipoprotein E (APOE) allele $\varepsilon 4$ associated with increased risk of AD. Physical and cognitive stimulating activities, statins and APOE allele $\varepsilon 2$ are associated with decreased risk of $\mathrm{AD}$.
Progressive memory deficits and cognitive impairment significantly affects patient's quality of life.

Pathological hallmark of $\mathrm{AD}$ is extracellular accumulation of $\mathrm{A} \beta$ amyloid plaques and intracellular neurofibrillary tangles. Mechanism by which $\mathrm{A} \beta$ and tau induce neuronal dysfunction and death may include direct impairment of synaptic transmission and plasticity, oxidative stress and neuroinflammation. Currently available treatment of AD includes cholinesterase inhibitors like donepezil, rivastigmine and galantamine. These drugs have modest efficacy and side effects like GI distress, altered sleep with unpleasant dreams and muscle cramps. So, there is a need 
for development of effective drugs to improve patients' quality of life.

Studies have revealed that individuals with elevated cholesterol levels are more susceptible to AD. Few reports suggest that degeneration that occurs in $\mathrm{AD}$ is mediated through modulation of cholesterol signalling in brain..$^{1-3}$

Statins are lipid lowering drugs with HMG-CoA reductase inhibitor action may have beneficial effects in treatment of $\mathrm{AD}$ due to their cholesterol lowering and other pleiotropic effects. ${ }^{4}$ Studies have been done to assess the effect of statins on cognitive function, some suggest cognitive improvement, some suggest cognitive decline and others finding no association. ${ }^{5-10}$ With this background present study has been taken up to evaluate the effect of statins on learning and memory in Alprazolam induced amnesia in albino mice employing memory models.

Objectives of the study was to evaluate the learning and memory effect of atorvastatin and simvastatin in alprazolam induced amnesia in albino mice.

\section{METHODS}

Albino mice of either sex, weighing around 25-30g with normal behaviour and activity were included in the study. Pregnant and diseased mice were excluded. Each group of mice was housed separately in a metallic cage, maintained under standard laboratory conditions with natural light and dark cycle of $12 \mathrm{~h}$ and had a free access to food and water. They were procured from animal house of J.J.M. Medical College, Davangere.

Animals were administered the drug every day morning for 14days. Experiment was carried out during $14^{\text {th }}$ and $15^{\text {th }}$ day between $9.00 \mathrm{am}$ and $3.00 \mathrm{pm}$. Total duration of study is 3 weeks which includes 1 -week acclimatization in laboratory prior to experiment. Animals were divided into four groups of 6 mice each. Study drugs Atorvastatin, Simvastatin and Piracetam were suspended in 1\% Carboxy methyl cellulose.

Group 1 was given amnestic agent Alprazolam (2mg/kg/p.o) alone for 14days. Group 2 was given Alprazolam (2mg/kg p.o) for 14days with Piracetam (400mg/kg p.o) from $8^{\text {th }}$ to $14^{\text {th }}$ day. Group 3 was given Alprazolam (2mg/kg alone p.o) for 14 days with Atorvastatin $\left(5 \mathrm{mg} / \mathrm{kg}\right.$, p.o.) from $8^{\text {th }}$ to $14^{\text {th }}$ day. Group 4 was given Alprazolam ( $2 \mathrm{mg} / \mathrm{kg}$ alone p.o) for 14days with Simvastatin $\left(5 \mathrm{mg} / \mathrm{kg}\right.$, p.o.) from $8^{\text {th }}$ to $14^{\text {th }}$ day. Piracetam is a nootropic drug, has been used as a standard in many research articles. ${ }^{5}$

On $14^{\text {th }}$ day, 90 mins after the administration of the last dose of drugs in the respective groups, mice were exposed to elevated plus maze and passive avoidance task for acquisition (learning) and retention (memory) was recorded $24 \mathrm{hrs}$ later on the $15^{\text {th }}$ day. ${ }^{5}$

\section{Laboratory models for testing learning and memory enhancing activity}

\section{Elevated plus maze (EPM)}

Mazes are the traditional tools in assessing learning and memory performance in laboratory animals. These are used to measure the cognitive performance, notably to evaluate the spatial long term memory in mice and rats.

The apparatus consists of two open arms measuring $16 * 5 \mathrm{~cm}$ for mice and two enclosed arms measuring $16 * 5 * 12 \mathrm{~cm}$ with an open roof, arranged so that the two open arms and two enclosed arms are opposite to each other. The maze is elevated to a height of $25 \mathrm{~cm}$. Transfer latency (TL) is a parameter of memory. The transfer latency was defined as the time in seconds taken by the animal to move into one of the enclosed arms. The experiment was performed in 2 stages. On day 14, the day of acquisition testing, each mice was placed at the end of an open arm facing away from the center and TL was recorded.

All four legs inside the closed arm was counted as an entry. Cut off time allotted for each mice was 90s. Those animals which could not enter the closed arms within the cut off time were excluded from the study. Retention testing was conducted $24 \mathrm{hrs}$ after the first trial and transfer latency was recorded in a similar manner as mentioned before. Shortened TL on next day was considered as an index of improvement of memory.

\section{Step-down type passive avoidance test (SDA)}

The step-down type of passive avoidance task has been used to examine the long term memory based on negative reinforcement. The apparatus consists of a transparent acrylic cage $(30 * 30 * 40 \mathrm{~cm}$ high) with a grid floor, inserted in a semi-soundproof outer box $(35 * 35 * 90 \mathrm{~cm})$. The cage is illuminated with a $15 \mathrm{~W}$ lamp during the experimental period. A wooden platform $(4 * 4 * 4 \mathrm{~cm})$ is fixed in the center of the grid floor. Electric shocks $(1 \mathrm{~Hz}, 500 \mathrm{msec}, 40$ V DC) are delivered to the grid floor with a commercially available isolated pulse stimulator. The training was carried out in two similar sessions. Each mouse was placed on the wooden platform in the centre of the cage. When the mouse steps down and places all its paws on the grid floor, shock was delivered for $15 \mathrm{sec}$. Step down latency (SDL), and the number of flinching reactions and vocalizations are measured. Animals showing SDL of 3$30 \mathrm{sec}$ during the first training session were preselected for second and retention trails. The second session was carried out 90 mins after the first. Animals staying $60 \mathrm{sec}$ on the platform were considered as remembering the task and no longer received electric shocks. The retention test was carried out $24 \mathrm{~h}$ after training, in a similar manner, except that electric shocks were not applied to the grid floor. Each mouse was again placed on the platform, and the SDL was recorded with an upper cut-off time of $300 \mathrm{sec}$. Amnestic drugs are expected to decrease the SDL in subsequent trails 
indicating the impairment of learning and retention tasks. ${ }^{11,12}$

\section{RESULTS}

The result was analyzed by calculating the mean values, standard deviation and standard error of mean followed by 'Paired $t$ test' to compare between acquisition $\left(14^{\text {th }}\right.$ day $)$ and retention $\left(15^{\text {th }}\right.$ day) within the groups. Differences in $14^{\text {th }}$ and $15^{\text {th }}$ day trial in all four groups were subjected to one way analysis of variance (ANOVA) followed by posthoc Tukey's test was done. $\mathrm{p}$ value $<0.05$ was considered as significant.

\section{In elevated plus maze model}

TL is the parameter used in this model. Shortened TL from $14^{\text {th }}$ to $15^{\text {th }}$ day trial means that mice have taken lesser time to move from open arm into one of the enclosed arm on subsequent day trial, considered as an index of improvement of memory. Alprozolam + Atorvastatin and Alprozolam + Simvastatin showed significant results compared to standard drug Piracetam $(\mathrm{p}<0.049)$ and $(p<0.007)$ respectively. No significant result was seen in Alprazolam only group. Results are given in Table 1, 2 and Figure 1.

Table 1: Comparison between different groups in EPM model.

\begin{tabular}{|llll|}
\hline Groups & $\begin{array}{l}\text { TL on 14 } \\
\text { day }\end{array}$ & $\begin{array}{l}\text { TL on 15 } \\
\text { day }\end{array}$ & $\begin{array}{l}\text { Paired } \\
\text { t test }\end{array}$ \\
\hline $\begin{array}{l}\text { Alprozolam } \\
\text { only (group 1) }\end{array}$ & $41.50 \pm 24.95$ & $56.17 \pm 15.18$ & $\mathrm{p}>0.05$ \\
\hline $\begin{array}{l}\text { Alprozolam + } \\
\text { Piracetam } \\
\text { (group 2) }\end{array}$ & $62.33 \pm 23.89$ & $13.50 \pm 5.17$ & $\mathrm{P}<0.003$ \\
\hline $\begin{array}{l}\text { Alprozolam }+ \\
\text { Atorvastatin } \\
\text { (group 3) }\end{array}$ & $60.33 \pm 22.33$ & $20.83 \pm 10.11$ & $\mathrm{P}<0.005$ \\
\hline $\begin{array}{l}\text { Alprozolam }+ \\
\text { Simvastatin } \\
\text { (group 4) }\end{array}$ & $40.83 \pm 29.36$ & $29.83 \pm 21.42$ & $\mathrm{P}<0.05$ \\
\hline
\end{tabular}

Table 2: Tukey's post Hoc multiple comparison TL.

\begin{tabular}{|ll|}
\hline Groups & Sig. \\
\hline 1 Vs 2 & $\mathrm{p}>0.05$ \\
\hline 1 Vs 3 & $\mathrm{p}<0.000$ \\
\hline 1 Vs 4 & $\mathrm{p}<0.000$ \\
\hline 2 Vs 3 & $\mathrm{p}<0.049$ \\
\hline 2 Vs 4 & $\mathrm{P}<0.007$ \\
\hline 3 Vs 4 & $\mathrm{p}>0.05$ \\
\hline
\end{tabular}

\section{In Step-down type passive avoidance model}

SDL is the parameter used in this model. Increased SDL from $14^{\text {th }}$ to $15^{\text {th }}$ day trial means that mice have stayed on wooden platform for longer time to escape from electric shock, thus indicating improvement in learning and retention tasks. Alprozolam + Simvastatin group showed highly significant result compared to standard drug Piracetam $(\mathrm{p}<0.001)$. Whereas with Alprozolam + Atorvastatin and Alprazolam only group results were insignificant ( $p>0.05)$. Results are given in Table 3, 4 and Figure 2.

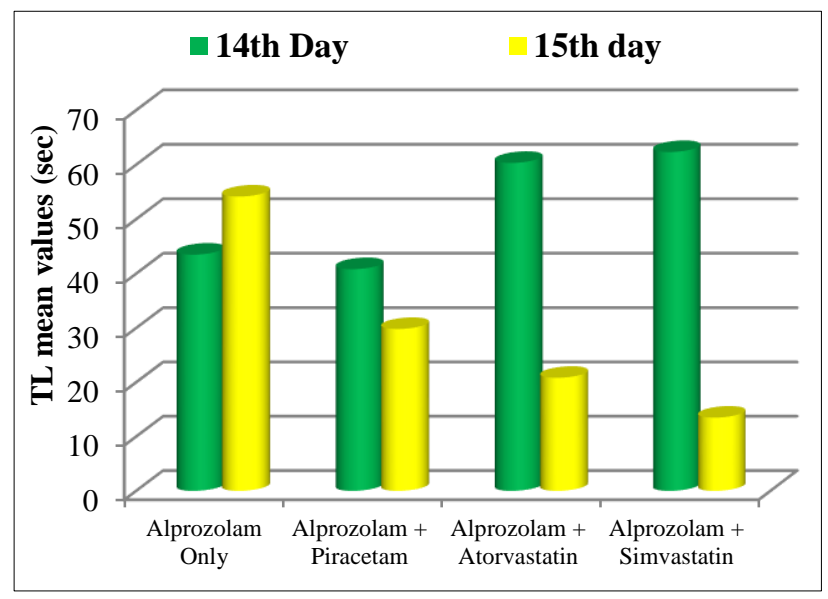

Figure 1: Percentage of mean values in EPM model.

Table 3: Comparison between different groups in SDA model.

\begin{tabular}{|llll|}
\hline Groups & $\begin{array}{l}\text { SDL on } \\
\mathbf{1 4}^{\text {th }} \text { day }\end{array}$ & $\begin{array}{l}\text { SDL on } \\
\mathbf{1 5}^{\text {th }} \text { day }\end{array}$ & $\begin{array}{l}\text { Paired } \\
\text { t test }\end{array}$ \\
\hline $\begin{array}{l}\text { Alprozolam } \\
\text { only } \\
\text { (group 1) }\end{array}$ & $7 \pm 5.40$ & $3.83 \pm 0.98$ & $\mathrm{p}>0.05$ \\
\hline $\begin{array}{l}\text { Alprozolam } \\
\text { + Piracetam } \\
\text { (group 2) }\end{array}$ & $42.33 \pm 34.11$ & $121 \pm 44.19$ & $\mathrm{P}<0.003$ \\
\hline $\begin{array}{l}\text { Alprozolam } \\
\text { +Atorvastatin } \\
\text { (group 3) }\end{array}$ & $30 \pm 21.47$ & $80.67 \pm 27.61$ & $\mathrm{P}<0.004$ \\
\hline $\begin{array}{l}\text { Alprozolam } \\
\text { + Simvastatin } \\
\text { (group 4) }\end{array}$ & $5.50 \pm 2.66$ & $26.17 \pm 10.09$ & $\mathrm{P}<0.02$ \\
\hline
\end{tabular}

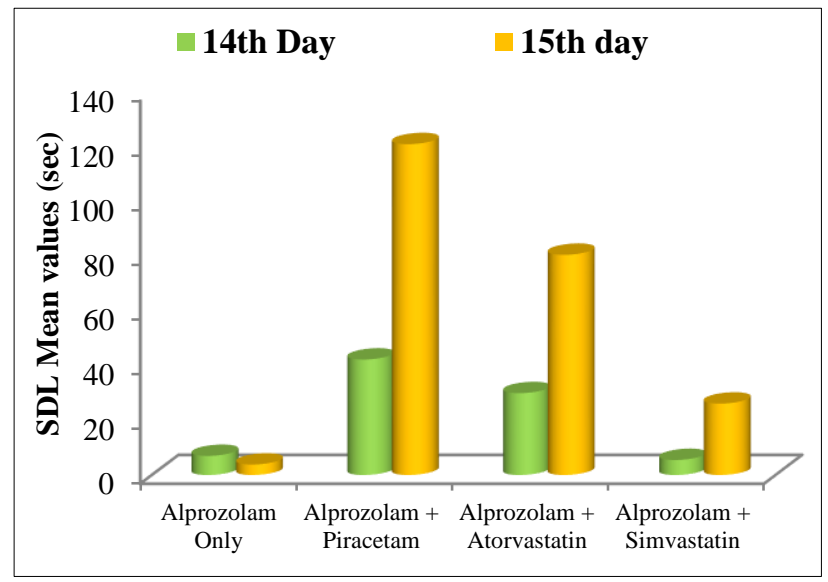

Figure 2: Percentage of mean values in SDA model. 
Table 4: Tukey's post Hoc multiple comparison SDL.

\begin{tabular}{|ll|}
\hline Groups & Sig. \\
\hline 1 Vs 2 & $\mathrm{p}>0.05$ \\
\hline 1 Vs 3 & $\mathrm{p}<0.002$ \\
\hline 1 Vs 4 & $\mathrm{p}>0.05$ \\
\hline 2 Vs 3 & $\mathrm{p}>0.05$ \\
\hline 2 Vs 4 & $\mathrm{p}<0.001$ \\
\hline
\end{tabular}

\section{DISCUSSION}

The treatment of age-related neurodegenerative diseases such as Alzheimer's disease (AD) is a challenge because of its complex pathology and not much drugs are available to counteract these pathological changes. The cholinergic hypothesis of $\mathrm{AD}$ postulates that low levels of Ach in synaptic cleft results in loss of cholinergic neurons in the nucleus basalis magnocellularis, which leads to cognitive decline. So, there is a need for development of drugs causing cognitive improvement and thus improving patients 'quality of life.

In present study, widely accepted learning memory paradigms like EPM and SDA models have been employed. In EPM model, both Atorvastatin and Simvastatin has shown significant decrease in TL when compared with standard drug Piracetam, indicative of improvement in memory. In SDA model, both statins showed an increase in SDL, which was statistically significant for simvastatin group when compared with the standard. Piracetam is used as standard nootropic drug in various research studies owing to its mechanism of increasing the cholinergic transmission.

A study by Manasa Ranjan Mishra, Syed Md. Javed, Sohail Ahmad, Lalith Mohan et al, on Effects of atorvastatin and simvastatin on learning and memory in aged Swiss albino mice suggested that memory enhancing property of statins was accompanied with decrease in plasma cholesterol and brain MDA levels. ${ }^{5}$

Another study by Milind PARLE, Nirmal SINGH et al, on Reversal of Memory Deficits by Atorvastatin and simvastatin in Rats suggested that Atorvastatin and simvastatin successfully reversed the memory deficits induced by high fat diet, Scopolamine/Alprazolam injection probably through their cholesterol dependent as well as cholesterol independent effects. ${ }^{6}$

A comprehensive review of studies investigating the effects of statins on cognitive function by Saurav Chatterjee, Parasuram Krishnamoorthy, Pragya Ranjan, Ahana Roy et al suggested that statins could be associated with a lower risk of dementia and AD through their antioxidant effect and effect on neurochemical markers. ${ }^{13}$

Statins, along with cholesterol lowering property they also have few pleiotropic effects like anti-inflammatory, immunomodulatory, improves endothelial function, antioxidant, and anti-thrombotic action and to some extent reduction in cognitive impairment. ${ }^{4}$ So the study result showing antiamnestic effect of statins might be due to their cholesterol lowering, anti-oxidant and anti-inflammatory properties.

\section{CONCLUSION}

The present study revealed that Atorvastatin and Simvastatin reversed Alprazolam induced amnesia. So, Statins used for various middle age disease conditions will be of potential use in treatment of neurodegenerative diseases like Alzheimer's disease. Further studies have to be conducted to firmly establish the results.

Funding: No funding sources

Conflict of interest: None declared

Ethical approval: The study was approved by the Institutional Ethics Committee

\section{REFERENCES}

1. Alzheimer's disease and other dementias. Kasper, Fauci, Hauser, Lango, Jameson. Harrison's principles of Internal medicine, $19^{\text {th }}$ Edition, volume 2, New Delhi, McGraw-Hill Education; 2015:2598-2608.

2. Joshi M, Gaonkar K, Mangoankar S, Satarkar S. Pharmacological investigation of Areca catechu for evaluation of learning, memory and behaviour in rats. Int Curr Pharm J. 2012;1(6):128-32.

3. Hersi M, Irvine B, Gupta P, Gomes J, Birkett N, Krewski D. Risk factors associated with the onset and progression of Alzheimer's disease: A systematic review of the evidence. J Neurotoxicol. 2017;61:14387.

4. Liao JK, Laufs U. Pleiotropic effects of statins. Annu. Rev. Annu Rev Pharmacol Toxicol. 2005 Feb 10;45:89-118.

5. Mishra MR, Javed SM, Ahmad S, Mohan L. Effects of atorvastatin and simvastatin on learning and memory in aged Swiss albino mice. Int J Pharm Sci Rev Res. Nov-Dec 2013;23(2)n 61:383-37.

6. Parle M, Singh N. Reversal of memory deficits by atorvastatin and simvastatin in rats. Yakugaku Zasshi. 2007;127(7):1125-37.

7. Stuart SA, Robertson JD, Marrion NV, Robinson ESJ. Chronic Pravastatin but not Atorvastatin impairs cognitive function in two rodent models of learning and memory. 2013;8(9);e75467. PLOS ONE. www.plosone.org.

8. Zhou B, Teramukai S, Fukushima M. Prevention and treatment of dementia or Alzheimer's disease by statins: a meta-analysis. Dementia and Geriatric Cognitive Disorders. 2007;23(3):194-201. [PubMed: 17259710]

9. Orsi A, Sherman O, Woldeselassie Z. Simvastatinassociated memory loss. Pharmacotherapy. 2001;21(6):767-9. 
10. Zamrini E, McGwin G, Roseman JM. Association between statin use and Alzheimer's disease. Neuroepidemiology. 2004;23(1-2):94-8.

11. Kulkarni SK. New drug discovery process, Hand Book of Experimental Pharmacology, $3^{\text {rd }}$ Edition, Delhi: Vallabh Prakashan; 2011:19-84.

12. Vogel HG. Psychotropic and Neurotropic Activity; Drug discovery and evaluation: pharmacological assays, $3^{\text {rd }}$ Edition, Germany; 2007:565-661.

13. Chatterjee S, Krishnamoorthy P, Ranjan P, Roy A, Chakraborty A, Sabharwal MS, et al. Statins and cognitive function: an updated review. Curr cardiol Rep. 2015 Feb 1;17(2):4.

Cite this article as: Shashikala $\mathrm{G}$, Jyothi $\mathrm{CH}$,

Shashikala GH. Evaluation of learning and memory effect of atorvastatin and simvastatin in alprazolam induced amnesia in mice. Int $\mathbf{J}$ Basic Clin Pharmacol 2018;7:1900-4. 